\title{
The Effect of Board Characteristics on Real Activities Manipulation in Tunisian Banks
}

\author{
Amina Zgarni ${ }^{1} \&$ Hassouna Fedhila ${ }^{2}$ \\ ${ }^{1}$ Faculty of Economic Sciences and Management of Tunis, International Finance Group, University of Tunis El \\ Manar, Tunisia \\ ${ }^{2}$ American University in North Africa, Tunisias \\ Correspondence: Amina Zgarni, Faculty of Economic Sciences and Management of Tunis, Tunisia. E-mail: \\ amina2302@yahoo.fr
}

Received: November 18, 2021

Accepted: December 8, $2021 \quad$ Online Published: December 30, 2021

doi:10.5539/ass.v18n1p47

URL: https://doi.org/10.5539/ass.v18n1p47

\begin{abstract}
The succession of financial scandals and resounding bank failures that characterized the economic environment over the past three decades have given more weight to governance mechanisms. As such, considered to be one of the most important internal governance mechanisms, the board of directors has shown its strengths in controlling earnings manipulation, in particular those linked to real activities. The aim of this paper is to examine the effect of board characteristics on real earnings management. Using panel data econometrics, on all Tunisian commercial banks over the period 2008-2019, we show that board gender diversity has a disciplinary role in real earnings management as measured by discretionary revenue on equity securities. However, we show that board independence increases the real earnings management. As for board size, board duality, as well as the number of meetings carried out per year by the board of directors, we prove that they have no significant effect on real earnings management.
\end{abstract}

Keywords: real earnings management, board of directors, discretionary revenue on equity securities

\section{Introduction}

The succession of scandals and resounding bankruptcies that have characterized the current economic environment have called into question the mechanisms of governance. As such, considered to be one of the most important internal governance mechanisms, the board of directors has shown its advantages in terms of controlling earnings manipulation. In fact, the legislator gives the board of directors a determining role in the process of corporate governance. Becher et al. (2003) claim that deregulation has increased the need to exercise more control through internal governance mechanisms, particularly the board of directors. Furthermore, the effectiveness of the control exercised by the board of directors on limiting the opportunistic behavior of managers depends on his characteristics (gender diversity, size, independence of its members, duality, etc.). Thus, given their indisputable role in economic growth, both nationally and internationally, effective boards of directors in banks remain essential. Recently, much empirical work has questioned the relationship between board characteristics and earnings management, especially those related to real activities. These studies find divergent results. Indeed, some studies find that certain characteristics can constrain real earnings management, others find that board characteristics accentuate real earnings management. While others find that these characteristics have no effect on real earnings management. The purpose of this paper is to examine the effect of board characteristics (gender diversity, independence, duality, size and meetings) on real earnings management in Tunisian commercial banks.

This paper is then structured as follows: In the second section, we present the theoretical foundations on the need to set up a board of directors and the hypotheses development. The third section presents the research methodology. In the fourth section, we present the results and the last section concludes the paper.

\section{Literature Review and Hypothesis Development}

According to Jones (1991), managers manage earnings of their firm with the objective of avoiding the transfer of wealth to regulatory authorities. the literature review enabled us to retain that there are two forms of earnings management; accounting earnings management and real earnings management. Accounting management is first 
carried out either by choosing the accounting methods or by applying these methods. then by the estimate of accruals which includes all the adjustments and which can be calculated by the difference between net profit and cash flow. However, according to Roychowdhury, (2006), earnings management through real activities is a technique that can be achieved through regular operational decisions such as abnormal cash flows, through discretionary spending including advertising spending and general and administrative spending or by production costs. In banks, bank managers use gains on the sale of securities as a technique for real earnings management (Moyer, 1990; Scholes et al., 1990; Beatty et al., 1995; Collins et al., 1995). However, managers generally use provisions for bad debts as the primary tool for managing earnings. But following the SOX law (2002) which was promulgated following the succession of financial scandals, the managers tend to the real earnings management rather than the accounting earnings management which is more detectable.

In fact, the current economic environment has necessitated a rethinking of governance mechanisms. In this context, considered to be the main actor in the governance process of the banking enterprise, the board of directors is responsible for the effectiveness of the governance mechanisms. On the other hand, according to the theories of governance, the missions of the board of directors are not limited to supervising the leaders for the benefit of the shareholders but also it helps to protect all the relationships that create value and to preserve and increase the productive character of the contract node. The board of directors is therefore the main actor in the governance process. As such, Fama and Jensen, (1983) state that the board of directors, as the legal authority in charge of controlling the decisions of the directors, plays an important role in the resolution of conflicts of interest between the shareholders and managers. Datar (2004), grants the board of directors the responsibilities for the appointment, control and possibly dismissal of the management team. It also defines long and medium-term objectives and important policies and oversees their application; which affects the costs of the bank. It considers the interests of recognized partners, including custodians, and directs activities and behavior towards compliance with laws and regulatory requirements. It also plays an important role in determining the ownership structure of the bank and its performance. However, the board, as an approving body, does not make the meaningful decisions, but helps managers make them and then ratify them. Moreover, the credibility of the mechanisms ensuring that banks are soundly governed and that technical and moral managerial failures are avoided is a decisive condition for the quality of governance of banks. This involves the way in which the affairs and activities of these institutions are managed by the board of directors. The latter fulfills a service function alongside that of control (Jhonson, Daily and Ellstrand, (1999). The board of directors can thus invite external experts to bring their knowledge and their expertise much needed for risk management. Dalton et al (1999) add that the board of directors makes it possible to create links with the environment of the firm and to absorb uncertainty. Indeed, decision-making requires relevant information that is difficult to obtain. as long as the uncertainty is great. Administrators are therefore at the origin of favorable transactions thanks to increased coordination between banks, reduced transaction costs and easier access to expertise, (Godart and Schatt, 2000). Thus, directors must be competent, responsible and able to supervise leaders and adapt to new changes (Cattrysse, 2002). Therefore, the effectiveness of the board of directors depends on its characteristics (its size, the presence of independent directors, its duality, etc.). Recently, other authors, such as Luo et al. (2017) Adamu et al (2017), emphasize the role played by the presence of women on the board in limiting the opportunistic strategies of managers and in particular in limiting the real earnings management. However, the review of the literature on the role of board characteristics in mitigating real earnings management shows divergent results.

\subsection{Gender Diversity and Real Earnings Management}

There are few studies examining the effect of gender diversity in the boardroom on actual management. In fact, it is only recently that these studies have gained momentum. Most of these studies have proven the effectiveness of the presence of women in mitigating results management. Although most of these studies focus on the accounting manipulation of results (Ghaleb et al., 2021), Zgarni and Fedhila (2021), Fan et al. (2019) etc.), new research proves that gender diversity in the board of directors negatively affects the actual management of results. As such, Luo et al. (2017) have shown that gender diversity in the board of directors constitutes and is an effective characteristic in limiting the effective management of results in Chinese companies. Likewise, Adamu et al. (2017) have proven the significant negative effect on results management practices through real activities

In this work, we propose that:

H-1: There is a negative relationship between board gender diversity and real earnings management.

\subsection{The Independence of the Board of Directors and the Real Earnings Management}

A review of the literature examining the effect of board independence on real earnings management shows divergent results. Garven (2015) have shown that there is a significant negative relationship between board 
independence and real earnings management. Similarly, Osma (2008) showed that more independent boards of directors limit the manipulation of R\&D spending in their study of a sample of British companies. In addition, Abbasi \& Qomi (2017) and Al-Haddad \& Whittington, (2019) have shown that there is a significant positive relationship between the independence of board members and real earnings management. In contrast, Kharashgah et al (2019) found no significant effect between board independence and real earnings management.

In this study we propose:

$\mathrm{H}-2$ : There is a negative relationship between board independence and real earnings management.

\subsection{Board Size and Real Earnings Management}

The effect of board size on earnings management has been extensively studied in previous research (Xie et al., 2003; Hashim \& Devi, 2008; Peasnell et al., 2005; Khalil \& Ozkan, 2016; Chouaibi et al., 2018; Orazalin, 2020). However, the results found are divergent some studies find that large board size increases real earnings management, but others have found that the reduced board size is more effective in mitigating earnings management. While, other studies have found no significant relationship between these two variables. As such, Dalton (1991) argues that when the size of the board is large, its capacity to perform its functions is reduced. Likewise, Lipton and Lorch (1992) argue that large boards may have been less effective than small boards. In this sense, Kharashgah et al (2019) found a significant positive relationship between board size and real earnings management. On the other hand, Abbasi \& Qomi (2017) showed that the large size of the board of directors will reduce the real earnings management.

In this work we propose:

H-3: There is a negative relationship between board size and real earnings management

\subsection{Duality of the Board of Directors and Real Earnings Management}

We speak of duality (dual structure) when there is a combination of the functions of CEO and Chairman of the Board of Directors, and of the monist structure when there is dissociation between the two functions. Jensen (1993), asserts that the CEO should not chair the board as he cannot separate his own interests from those of the shareholders. This is how the dual structure significantly promotes the power of manager within the board and therefore reduces the effectiveness of the control mechanisms. The studies dealing with the effect of board duality on real earnings management are divergent. As such, Alhmood et al (2020) found that the board duality limits the real earnings management in a sample of Ammen companies. However, Chang \& sun (2008) as well as Abbasi \& Qomi (2017) have shown that the duality of the board of directors increases the real earnings management.

In this study we propose:

H-4: There is a negative relationship between board duality and real earnings management.

\subsection{Number of Board Meetings and Real Earnings Management}

An overview of the financial and accounting literature on the effect of the number of meetings held by the board of directors on the actual management of results, allows us to highlight that all of this work is also contrasted. Their results swing between the effectiveness and ineffectiveness of this characteristic in its exercise of control. Thus, Kharashgah et al (2019) have shown that there is a significant negative relationship between the number of meetings carried out by the board of directors and real earnings management. nevertheless, Adamu et al (2017) find a significant positive relationship between the number of meetings and the manipulation of results via real activities. As for, Susanto \& Pradipta (2016) have shown that the number of meetings does not reduce the real earnings management.

In this study we propose:

H-5: There is a negative relationship between board meetings and real earnings management.

\section{Research Methodology}

\subsection{Sample and Study Period}

In order to test our hypotheses, we based ourselves on a sample of ten Tunisian commercial (or deposit) banks which are listed on the Tunis Stock Exchange Commission (TSEC). The study period lasts from 2008 to 2019 giving rise to 120 observations.

\subsection{Model to Estimate and Measurement of Variables}

Empirical studies use three main measures of real earnings management (Roychowdhury, 2006; Cohen et al., 
2008), including abnormal cash flows, discretionary spending and production costs, to measure the behavior of real earnings manipulation. In our study, we propose to choose discretionary revenue on the sale of equity securities, which is the real earnings management technique most practiced in the banks in our sample. In fact, it was with Bartov (1993) that this measure was used for the first time. So, in our study, like Bartov (1993), Gunny, (2005), and Zang (2007), we therefore propose to use discretionary revenue on the sale of equity securities to measure real earnings management in banks. To do this, we'll use the two-step approach:

*1st step:

Revenue from the sale of equity securities is divided into two parts:

* Non-discretionary revenue on the sale of securities. These products will be estimated by the following model:

$$
\text { PCNDit }=\widehat{\alpha}_{0}+\widehat{\alpha}_{1} \frac{V C_{i t}}{A T_{i t-1}}(1)
$$

* Discretionary revenue from the sale of equity securities

$\frac{R E S_{i t}}{T A_{i t-1}}=\frac{D R E S_{i t}}{T A_{i t-1}}+N D R E S_{i t}$

*2nd step:

Calculation of discretionary revenue from the sale of equity securities:

$$
\left.\frac{D R E S}{A T_{i t-1}}=\hat{\varepsilon}_{i t}=\frac{R E S_{i t}}{T A_{i t-1}}-\text { PCNDit }=\frac{R E S_{i t}}{T A_{i t-1}}-\widehat{\propto}_{0}+\widehat{\propto}_{1} \frac{C V_{i t}}{T A_{i t-1}}\right]
$$

With:

DRES $_{\mathrm{it}}$ : discretionary revenue from the sale (capital gain - loss) of equity securities made by bank $\mathrm{i}$ on date $\mathrm{t}$. They correspond to non-discretionary revenue on disposal;

$\mathrm{CV}_{\mathrm{it}}$ : the sale value of equity securities realized by bank $\mathrm{i}$ on date $\mathrm{t}$;

$\mathrm{TA}_{\mathrm{it}-1}$ : the total assets of bank $\mathrm{i}$ at date $\mathrm{t}-1$;

$\mathrm{a}_{0,1}$ : the model coefficients are estimated on Panel data during the period 2008-2019 estimate.

To achieve our objective, we propose the estimation of discretionary income on disposal of equity securities based on the different board characteristics (gender diversity, independence, duality, size and meetings). Our model will therefore be as follows:

$$
\begin{aligned}
D_{R E S_{i t}=} & \beta_{0}+\beta_{1} \text { BSIZE }_{i t}+\beta_{2} I B I N D_{i t}+\beta_{3} B D U A_{i t}+\beta_{4} B M E E T_{i t}+\beta_{5} B_{C O M_{i t}}+\beta_{6} R O A_{i t} \\
& +\beta_{7} L_{A S S E T_{i t}}+\beta_{8} B I G_{i t}+\beta_{9} A G E_{i t}+\varepsilon_{i t}(3)
\end{aligned}
$$

Table 1. Variables Measurement

\begin{tabular}{ll}
\hline Variables & Mesurement \\
\hline DRES & Discretionary revenue on equity securities \\
BGD & Board gender diversity: number of women on the board divided by the total number of its members \\
BIND & Board independence: the number of independent members divided by the total number of its members \\
BDUAL & Board duality: binary variable equal to 1 if duality exists and 0 otherwise \\
BMEET & Board meeting: The number of meetings per year held by the board of directors of bank i in year $\mathrm{t}$; \\
BSIZE & Board size: The number of members in the board of directors of bank i in year $\mathrm{t}$; \\
LASSET & Size of bank i in year t: measured by the natural logarithm of the total assets of the bank \\
ROA & Return on assets of bank i in year t: measured by net income divided by total assets \\
BIG & The belonging of the external auditor to the Big 4 group of the bank $\mathrm{i}$ to the year $\mathrm{t}$ : measured by a \\
& binary variable which is equal to 1 if the bank is audited by a BIG4 and 0 otherwise. \\
AGE & Age of bank i in year $\mathrm{t}$
\end{tabular}




\section{Regression Results}

\subsection{Descriptive Statistics}

The results of the descriptive statistics are presented in Table 2 below.

Table 2. Descriptive statistics of the study variables

\begin{tabular}{cccccc}
\hline Variable & Moyenne & Min & Max & Ecart Type. & Observation \\
\hline DRES & 0.026613 & -0.020525 & 0.153192 & 0.036932 & 120 \\
BGD & .158455 & 0 & .464558 & .070222 & 120 \\
BSIZE & 11.18522 & 8 & 20 & 2,851126 & 120 \\
BIND & 0.244741 & 0 & .350000 & 0.382787 & 120 \\
BDUAL & 0,725497 & 0 & 1.000000 & 0,384588 & 120 \\
BMEET & 4.14220 & 2.000000 & 8.000000 & 1.51659 & 120 \\
\hline
\end{tabular}

According to the descriptive statistics reported in Table 2, the 10 Tunisian listed commercial banks recorded between 2008 and 2019, the revenue on the sale of securities is $2.66 \%$ on average. With a standard deviation of $3.69 \%$ indicating a low volatility of this variable in our sample. Regarding board characteristics, descriptive statistics show that board gender diversity is $15.84 \%$ on average with a minimum value of 0 and a maximum value of 46.45 , with a standard deviation of $7.02 \%$ indicating a low volatility within our sample. The average board size of 11 members with a minimum value of 8 and a maximum value of 20 . The standard deviation shows a value of $285 \%$ indicating high volatility in the board size within our sample. As for the board independence, it is $24.47 \%$ on average varying between 0 and $35 \%$. The standard deviation is $38.27 \%$. The board duality is $72.54 \%$ on average with a minimum value of 0 and a maximum value of 1 . The standard deviation is $38.45 \%$. Regarding the number of board of directors' meetings, the results of the descriptive analysis show that the average number of meetings of audit committee members in Tunisian commercial banks is almost 4 times a year, with a minimum of 2 and maximum of 8 meetings per year. The typical deviation is 151.65 indicating a high volatility of this variable within our sample.

\subsection{Analysis of the Regression Results}

Table 3. Regression results of the estimate of the effect of audit quality on discretionary revenue on equity securities

\begin{tabular}{ccccc}
\hline & Coefficient & Std. Err. & $\mathrm{z}$ & $\mathrm{P}>|\mathrm{z}|$ \\
\hline BGD & -0.005808 & 0.002046 & -2.162322 & $0.0320^{* *}$ \\
BIND & 0.043591 & 0.023576 & 1.848986 & $0.0675^{* *}$ \\
BDUAL & -0.011994 & 0.011831 & -1.013735 & 0.3132 \\
BMEET & $3.32 \mathrm{E}-05$ & 0.001713 & 0.019394 & 0.9846 \\
BCOM & -0.005808 & 0.015518 & -0.374247 & 0.7090 \\
LASSET & -0.002317 & 0.004357 & -0.531881 & 0.5960 \\
ROA & -0.339398 & 0.116345 & -2.917160 & $0.0044^{* * *}$ \\
BIG & -0.006249 & 0.003888 & -1.607334 & 0.1112 \\
AGE & 0.005850 & 0.011304 & 0.517562 & 0.6059 \\
Const & 0.016672 & 0.058955 & 0.282797 & 0.7779 \\
\hline
\end{tabular}

***: significant at $1 \%, * *$ significant at at $5 \%$, * significant at $10 \%$

The results of our regression presented in table 3 show that there is a significant negative relationship between board gender diversity and discretionary revenue on equity securities. Our hypothesis H-1 is thus confirmed. Therefore, the presence of women on the board of directors reduces real earnings management practices in the banks in our sample. This result corroborates with that found by Luo et al. (2017) and Adamu et al. (2017). Regarding the independence of the board of directors, we show that it has a significant positive effect on the real earnings management. Which invalidates our $\mathrm{H}-2$ hypothesis. This result agrees with that found by Osma (2008), Abbasi \& Qomi (2017) and Al-Haddad \& Whittington, (2019). However our result contradicts that found by 
Kharashgah et al. (2019) who found no significant effect between board independence and real earnings management. The regression results also show that board size has no significant effect on real earnings management. Our H-3 hypothesis therefore turns out to be invalid. This result does not agree with the basic theoretical foundations stipulating that a large board is less effective than a small board. Indeed, the average boards size of the banks in our sample is 11 members, which is relatively high. Furthermore, our result diverges from that found by Kharashgah et al. (2019) who found a significant positive relationship between board size and earnings management. As for the duality of the board of directors, we show from our regression results that it has no significant effect on real earnings management. Our H-4 hypothesis therefore turns out to be invalid. Our result is in contradiction with that found by Nuanpradit (2019) and Kharashgah et al. (2019) as well as Al-Haddad \& Whittington (2019) who showed that there is a significant positive relationship between the duality of the board of directors and real earnings management. Likewise, our result does not agree with Abbasi \& Qomi (2017) who showed that the duality of the board of directors increases real earnings management. Finally, the number of meetings held per year by the board of directors has no significant effect on real earnings management. Hence, the invalidation of our hypothesis H-5. This result agrees with the results of Chandren et al. (2015). In addition, our result is opposed to that found by Adamu et al. (2017), who proved a significant positive relationship between these two variables. Likewise, our result does not agree with Kharashgah et al (2019) having shown that there is a significant negative relationship between number of board meetings and real earnings management. Regarding the control variables, the regression results show that the bank's accounting performance measured by the return on assets (ROA) has a significant negative effect on discretionary revenue on the sale of securities. However, the effect of audit quality measured by membership of a BIG4 group auditor as well as the size of the bank (LASSET) on real earnings management is negative but not significant. Similarly, the effect of the bank's age on discretionary revenue on the sale of securities is positive but not significant in the banks in our sample.

\section{Conclusion}

This paper examines the effect of board characteristics (gender diversity, independence, size, duality and number of meetings) on real earnings management. We have been able to show that gender diversity limits real earnings manipulation. Furthermore, we have shown that the independence of the board of directors positively affects real earnings management. On the other hand, we have shown that board size and board duality as well as the number of meetings carried out by the board of directors has no significant effect on real earnings management. So, according to our study, it turns out that the characteristics of the board of directors, especially the board gender diversity, have an important determining role in limiting discretionary real practices. Thus, our study contributes to the literature in two essential points, the first being that it is a subject little studied in the literature because most of the studies relate to the accounting earnings management (Xie et al., 2003; Peasnell et al., 2005; Orazalin, 2020; Zgarni \& Fedhila, 2021, etc.). The second is that our study relates to a regulated sector, that of banks. In fact, researches on banks remains timid compared to research on unregulated corporate sectors.

However, like all research, this study is not without its limitations. The first limitation is that board gender diversity is measured simply by the sheer presence of women on the board. Other measures such as the proportion of independent women on the board, their expertise may shed more light on the contribution of female representation on the board of directors. The second limitation is that our study is limited to certain board characteristics (gender diversity, independence, size, duality and number of meetings), other characteristics such as the age of the directors, their nationality can have a considerable effect on real earnings management. Finally, in our study, we measured the real earnings management by discretionary revenue on the sale of securities. Other measures proposed in the literature may give more reliable results such as securitization, which is a technique newly imposed by the Tunisian regulatory authorities.

\section{References}

Abbasi, E., \& Qomi, A. (2017). The Effect of the Characteristics of Board of Directors on Real Earnings Management. International Journal of Finance and Managerial Accounting, 2(6), 57-69. Retrieved from https://ijfma.srbiau.ac.ir/article_11376.html

Adamu, A. I., Ishak, R. I., \& Chandren, B. S. (2017). The Effect of Board Attributes on Real Earnings Management in Nigerian Financial Institutions. Journal of Accounting, Business and Finance Research, 1(1), 76-83. https://doi.org/10.20448/2002.11.76.83

Al-Haddad, L., \& Whittington, M. (2019). The impact of corporate governance mechanisms on real and accrual earnings management practices: Evidence from Jordan. Corporate Governance, 19(6), 1167-1186. https://doi.org/10.1108/CG-05-2018-0183 
Alhmood, M. A., Shaari, H., \& Al-dhamari, R. (2020). CEO Characteristics and Real Earnings Management in Jordan. International Journal of Financial Research, 11(4), 255-266. https://doi.org/10.5430/ijfr.v11n4p255

Bartov, A. (1993). The timing of asset sales and earnings manipulation. The Accounting Review, 68(4), 840-855. Retrieved from https://www.jstor.org/stable/248507

Beatty, A., Chamberlain, S., \& Maglolo, J. (1995). Managing financial reports of commercial banks: The influence of taxes, regulatory capital, and earnings. Journal of Accounting Research, 33(2), 231-262. https://doi.org/10.2307/2491487

Becher, D. A., Campbell, T. L., \& Frye, M. B. (2003). Incentive compensation for bank directors: The impact of deregulation. Federal Reserve Bank of Chicago, Mai, 423-443. https://doi.org/10.1086/431441

Cattrysse, J. (2002). Reflexion on corporate governance and role of internal auditors. SSRN Working Paper. Retrieved from http://ssrn.com/abstract=485364.400-417

Datar, M. K. (2004). Corporate Governance in Financial Intermediaries. Economic and Political Weekly, 39(4), 328-332. Retrieved from https://www.jstor.org/stable/4414549

Fama, E. F., \& Jensen, M. C. (1983). Separation of ownership and control. The Journal of Law and Economics, 2(26), 301-325. Retrieved from https://www.jstor.org/stable/725104

Garven, S. (2015). The Effects of Board and Audit Committee Characteristics On Real Earnings Management: Do Boards And Audit Committees Play A Role In Its Promotion Or Constraint? Academy of Accounting and Financial Studies Journal, 19(1). $\quad$ Retrieved from https://scholarworks.moreheadstate.edu/msu_faculty_research/229/

Ghaleb, B. A. A., Ayesh Qaderi, S., Almashaqbeh, A., \& Qassem, A. (2021). Corporate social responsibility, board gender diversity and real earnings management: The case of Jordan. Cogent Business \& Management, 8(1), 19. https://doi.org/10.1080/23311975.2021.1883222

Gunny, K. (2005). What are the Consequences of Real Earnings Management? Document de travail, University of Colorado. Retrieved from https://www.proquest.com/openview/21fd8dd32fa1ffd80448e24f015fae5f/ 1 ?pq-origsite $=$ gscholar $\& \mathrm{cbl}=18750 \&$ diss $=\mathrm{y}$

Hashim, H. A., \& Devi, S. S. (2008). Board characteristics, ownership structure and earnings quality: Malaysian evidence. Research in Accounting in Emerging Economies, 8, 97-123. https://doi.org/10.1016/S1479-3563(08)08004-3

Jones, J. (1991). Earnings management during import relief investigations. Journal of Accounting Research, 29(2), 193-228. https://doi.org/10.2307/2491047

Kharashgah, K. A., Amran, N. A., \& Ishak. (2019). Board of directors' structure and Real Earnings Management: Jordanian Evidence. International Journal of Academic Research in Business and Social Sciences, 9(2), 728-746. https://doi.org/10.6007/IJARBSS/v9-i12/6785

Lipton, L., \& Lorsch, J. (1992). A Modest Proposal for Improved Corporate Governance. The Business Lawyer, 48, 59-77. https://www.jstor.org/stable/40687360

Luo, J. H., Xiang, Y., \& Huang, Z. (2017). Female directors and real activities manipulation: Evidence from China. China Journal of Accounting Research, 10(2), 141-166. https://doi.org/10.1016/j.cjar.2016.12.004

Moyer, S. (1990). Capital adequacy ratio regulations and accounting choices in commercial banks. Journal of Accounting and Economics, 13, 123-154. https://doi.org/10.1016/0165-4101(90)90027-2

Nuanpradit, S. (2019). Real earnings management in Thailand: CEO duality and serviced early years. $\begin{array}{llll}\text { Asia-Pacific Journal of Business } & \text { Administration, } & 11(1),\end{array}$ https://doi.org/10.1108/APJBA-08-2018-0133

Orazalin, N. (2020). Board gender diversity, corporate governance, and earnings management: Evidence from an emerging market. Gender in Management: An International Journal, 35(1), 37-60. https://doi.org/10.1108/GM-03-2018-0027

Osma, B. G. (2008). Board Independence and Real Earnings Management: The Case of R\&D Expenditure. Corporate governance, 16(2), 116-131. https://doi.org/10.1111/j.1467-8683.2008.00672.x

Khalil, M., \& Ozkan, A. (2016). Board Independence, Audit Quality and Earnings Management: Evidence from Egypt. Journal of Emerging Market Finance, 15(1), 84-118. https://doi.org/10.1177/0972652715623701

Chouaibi, J., Harres, M., \& Ben Brahim, N. (2018). The Effect of Board Director's Characteristics on Real 
Earnings Management: Tunisian-Listed Firms. Journal of the Knowledge Economy, 9(3), 999-1013. https://doi.org/10.1007/s13132-016-0387-3

Peasnell, K. V., Pope, P. F., \& Young, S. (2005). Board Monitoring and Earnings Management: Do Outside Directors Influence Abnormal Accruals? Journal of Business Finance \& Accounting, 32(7-8), 1311-1346. https://doi.org/10.1111/j.0306-686X.2005.00630.x

Roychowdhury, S. (2006). Earnings management through real activities manipulation. Journal of Accounting and Economics, 42(3), 335-370. https://doi.org/10.1016/j.jacceco.2006.01.002

Scholes, M. S., Wilson, P. G., \& Wolfson, M. A. (1990). Tax planning, Regulatory capital planning and financial reporting strategy for commercial banks. The review of Financial Studies, 3(4), 625-650. https://doi.org/10.1093/rfs/3.4.625

Susanto, Y. K., \& Pradipta, A. (2016). Corporate Governance and Real Earnings Management. International Journal of Business, Economics and Law, 9(1), 17-23. Retrieved from http://www.ijbel.com/wp-content/uploads/2016/05/K9_82.pdf

Visvanathan, G. (2008). Corporate governance and real earnings management. Academy of Accounting and Financial Studies Journal, 12(1), 9-22. Retrieved from https://www.proquest.com/openview/80d71cff50d1 3841b 5c1f416a58a43dd/1?pq-origsite $=$ gscholar\&cbl $=29414$

Xie, B., Davidson, W. N., \& DaDalt, P. J. (2003). Earnings management and corporate governance: The role of the board and the audit committee. Journal of Corporate Finance, 9, 295-316. https://doi.org/10.1016/S0929-1199(02)00006-8

Zang, A. (2007). Evidence of the tradeoff between real manipulation and accrual manipulation. Working Papers, University of Rochester. Retrieved from https://ssrn.com/abstract $=1891759$

Zgarni, A., \& Fedhila, H. (2021). Can Board Gender Diversity Better Control Earnings Manipulation: Evidence from Banking Industry. Asian Social Science, 17(7), 29-39. https://doi.org/10.5539/ass.v17n7p29

\section{Copyrights}

Copyright for this article is retained by the author(s), with first publication rights granted to the journal.

This is an open-access article distributed under the terms and conditions of the Creative Commons Attribution license (http://creativecommons.org/licenses/by/4.0/). 